\title{
Geology of Selected
}

Quadrangles in

Rhode Island

GE O L O G I C A L S U R V E Y B U L L E T I N 1158

This bulletin was published

separately as chapters $A-E$

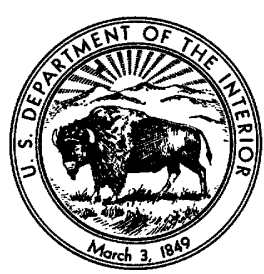


UNITED STATES DEPARTMENT OF THE INTERIOR STEWART L. UDALL, Secretary

GEOLOGIGAL SURVEY

Thomas B. Nolan, Director 


\section{CONTENTS}

[The letters in parentheses preceding titles indicate separately published chapters]

(A) Bedrock geology of the Coventry Center quadrangle, Rhode Island, by George E. Moore, Jr.

(B) Bedrock geology of the Crompton quadrangle, Rhode Island, by Alonzo W. Quinn.

(C) Bedrock geology of the Wickford quadrangle, Rhode Island, by Roger $\mathbf{B}$. Williams.

(D) Bedrock geology of the Tiverton quadrangle, Rhode Island-Massachusetts, by Samuel J. Pollock.

(E) Bedrock geology of the Kingston quadrangle, Rhode Island, by George $\mathbf{E}$. Moore, Jr. 
, 


\section{3edrock Geology of the}

Coventry Center

Quadrangle, Rhode Island

, GEORGE E. MOORE, JR.

EOLOGY OF SELECTED QUADRANGLES IN RHODE ISLAND

E O L O G I C A S U R V EY B U L L E T I N $1158-\mathrm{A}$

repared in cooperation with the State Rhode Island Development Council

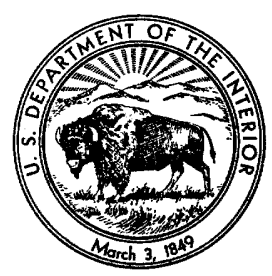




\section{UNITED STATES DEPARTMENT OF THE INTERIOR}

STEWART L. UDALL, Secretary

\section{GEOLOGICAL SURVEY}

Thomas B. Nolan, Director 


\section{CONTENTS}

\begin{tabular}{|c|c|}
\hline & \\
\hline & \\
\hline 品 & \\
\hline ormations & \\
\hline $\operatorname{rian}(?)$ & \\
\hline Gneiss and schist & \\
\hline Devonian(?) or older & \\
\hline Scituate granite gneiss & \\
\hline alaskite gneiss & \\
\hline Ten Rod granite gneiss & \\
\hline granite & \\
\hline eiss__ & \\
\hline older to Pennsylvanian(?) & \\
\hline - & \\
\hline gmatite, and aplite & \\
\hline ions & \\
\hline 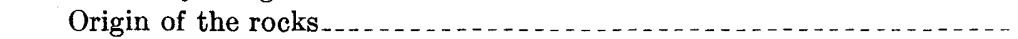 & \\
\hline (-1 & \\
\hline 思 & \\
\hline te gneiss and Hope Valley alaskite gneiss & \\
\hline gneiss & \\
\hline ite & \\
\hline Quartz diorite gneiss & \\
\hline Gabbro & \\
\hline etamorphism & \\
\hline eology & \\
\hline erature & \\
\hline
\end{tabular}

\section{ILLUSTRATION}

Plate 1. Bedrock geology of Coventry Center quadrangle, Rhode Island..-

In pocket

\section{'IABLE}

TABLE 1. Modes of rocks from the Coventry Center quadrangle........ 



\title{
GEOLOGY OF SELECTED QUADRANGLES IN RHODE ISLAND
}

\section{BEDROCK GEOLOGY OF THE GOVENTRY GENTER QUADRANGLE, RHODE ISLAND}

\author{
By George E. Moore, Jr.
}

\begin{abstract}
ABSTMRAOT
The Coventry Center quadrangle, in west-central Rhode Island, is underlain by a complex of crystalline rocks, which extends northward into Massachusetts and westward into Connecticut. This crystalline area is bordered on the east by the northerly trending synclinal Narragansett basin, which contains sedimentary rocks of Pennsylvanian age. Rocks of this basin overlie the older rocks with angular unconformity and nonconformity.

Six bedrock units ranging in age from Precambrian(?) to Devonian(?) or older and a seventh unit possibly of younger age were mapped. Precambrian(?) gneiss and schist exposed near the northwest corner of the area are mostly of sedimentary origin and probably belong to the Blackstone series or the Woonasquatucket formation. Dark-gray to light-gray quartz-feldspar-biotite gneiss and schist are the more abundant rock types.

Scituate granite gneiss, Hope Valley alaskite gneiss, Ten Rod granite gneiss, fine-grained granite, and quartz diorite gneiss are plutonic rocks of Devonian(?) or older age metamorphosed in different degrees. The Scituate is a mediumto coarse-grained light-colored gneiss with flat oval splotches of biotite alined so as to produce a strong lineation and moderate to weak foliation. The gneiss is cut by numerous shear zones; the sheared rock is fine grained, displays well developed cleavage, and locally contains muscovite, chlorite, and garnet. The shear zones and the cleavage in the shear zones in most places do not parallel the foliation in the surrounding rock. The Hope Valley alaskite gneiss, a medium-grained gneiss, contains flattened rod-shaped aggregates of quartz that are in strong lineation. The alaskite gneiss grades into the Scituate, suggesting contemporaneity. The Ten Rod granite gneiss is a pinkish-gray to gray fineto medium-grained porphyritic gneiss having moderate to strong foliation and lineation. It occurs in relatively small, generally concordant bodies, which are intrusive into the Scituate granite gneiss. Dikes of Ten Rod with flow structure parallel to the dike walls indicate an igneous origin. The fine-grained granite occurs as lens-shaped bodies, irregularly shaped bodies, sills, and dikes in the Scituate granite gneiss; the granite ranges from strongly foliated and lineated to nearly massive. It is younger than the Scituate and probably about equivalent in age with the Ten Rod. Some dikes of both Ten Rod granite gneiss and fine-grained granite show a primary flow foliation parallel to the dike walls;
\end{abstract}


other dikes have a secondary foliation at a high angle to the dike walls and parallel to the foliation in the enclosing rock. The quartz diorite gneiss is a well-foliated light- to medium-gray medium-grained gneiss, which is intrusive into the adjacent Precambrian(?) gneiss and schist; its age relative to other formations of the area is unknown.

Coarse-grained gabbro, which has moderate to strong primary flow foliation expressed by tablets of plagioclase oriented parallel to the walls of the body, is intrusive into the Precambrian(?) gneiss and schist. It could be the youngest rock in the area because it shows no effect of the regional metamorphism that affected the Pennsylvanian rocks of the Narragansett basin.

In most of the area the foliation, lenticular intrusives, and bedding trend north or northeast and dip west or northwest at low to moderate angles; lineation plunges north-northwest at low to moderate angles.

The Precambrian(?) gneiss and schist were subjected to regional metamorphism, of middle grade, before the intrusion of the Scituate granite gneiss and the quartz diorite gneiss. The age of this metamorphism could range from Precambrian to Devonian(?). A subsequent period of metamorphism was initiated by the emplacement of the Devonian(?) or older intrusives. Feldspathization of the Precambrian(?) gneiss and schist adjacent to the intrusives occurred at this time. High shearing stresses must have existed at several times during the emplacement of these intrusives to account for the foliation across some discordant bodies of Ten Rod granite gneiss and fine-grained granite. Shear zones, and cleavage and metamorphic minerals in the shear zones, were probably formed near the end of the Devonian(?) or older orogeny, but they could be Pennsylvanian in age.

\section{INTRODUCTION}

The Coventry Center quadrangle, in west-central Rhode Island, is an area of mature dissection modified by glaciation. Outcrops are abundant locally but are notably absent from most of the larger drumlin-shaped hills.

The quadrangle was mapped in 1956 and 1957. Previously, W. A. Oliver, Jr., and G. H. Springer had mapped part of the northeast and northwest corners of the area, respectively. All outcrops mapped by Springer and most of those mapped by Oliver were reexamined by the author.

\section{GEOLOGIC FORMATIONS}

Six rock units ranging in age from Precambrian(?) to Devonian(?) or older and a seventh unit possibly of younger age were mapped (pl. 1). The Precambrian(?) gneiss and schist are mostly of sedimentary origin but possibly in part of volcanic origin. The Devonian(?) or older rocks are metamorphosed plutonic rocks. Unmetamorphosed gabbro is of Devonian(?) or older to Pennsylvanian or younger age.

The geologic ages of the Scituate granite gneiss, Hope Valley alaskite gneiss, and Ten Rod granite gneiss, as determined from field observations by several geologists in Rhode Island, have been corroborated by lead-alpha age determinations made by the U.S. Geological Survey on zircon contained in these rocks (Quinn and others, 1957). 


\section{PRECAMBRIAN (?)}

\section{GNEISS AND SCHIST}

The largest body of gneiss and schist is near the northwest corner of the quadrangle. Most of the gneiss and schist unit is in septa between bodies of plutonic rocks; the rest occurs as inclusions in plutonic rock. Correlation of these rocks with those at the type localities of the several metasedimentary formations of northern Rhode Island is uncertain because part of the intervening area has not been mapped. The gneiss and schist extend northward into the Clayville quadrangle, where they were mapped by R. J. Frost ${ }^{1}$ as a part of the Woonasquatucket formation. These rocks in the Coventry Center quadrangle, however, do not contain large grains of bluish quartz, which are typical of the Woonasquatucket formation of the Georgiaville and North Scituate quadrangles (Richmond, 1952; Quinn, 1951). In the Hope Valley quadrangle, metasedimentary rocks similar to those of the mapped area in respect to structural relations with the Scituate granite gneiss and in degree and kind of metamorphism were correlated with the Blackstone series (Moore, 1958).

Layering believed to reflect bedding is prominent in outcrops of gneiss and schist about 0.3 mile northeast of the intersection of Bennett Hill and Moosup Valley Roads. In most places the layering appears to be parallel to foliation, but locally, as in the outcrop 0.59 mile N. $20^{\circ}$ E. of the intersection mentioned above, the two structures are subparallel. The thickness of these rocks is unknown; small folds can be seen in places, and bedding attitudes indicate the presence of larger folds.

The most abundant rock, perhaps as much as 80 percent of the formation, is light- to dark-gray fine- to coarse-grained quartzfeldspar-biotite gneiss, in part schistose, locally with some muscovite or hornblende, or traces of garnet (table 1, columns 1 and 2). The coarser gneiss contains much feldspar, some as small metacrysts, and some of the gneiss has weakly developed augen structure. Biotite ranges from 4 to 30 percent of the rock but is commonly 8 to 10 percent.

Schist, much of which is almost gneissic, is fine to medium grained, medium to dark gray, and is composed mainly of quartz, feldspar, and perhaps as much as 50 percent biotite. Locally it contains muscovite, garnet, hornblende, magnetite, chlorite, or other minor accessories (table 1, column 3). Thin beds of very dark gray fine-grained hornblende schist are locally intercalated with other rocks as in exposures about 0.17 mile east of the northwest corner of the quadrangle. A layer of dark-gray fine-grained quartz-feldspar-biotite schist, about

1 Frost, R. J., 1950, Bedrock geology of the south half of the Clayville quadrangle of Rhode Island : Providence, R.I., Brown University master's thesis. 
TABLE 1-Modes of rocks from the Coventry Center quadrangle

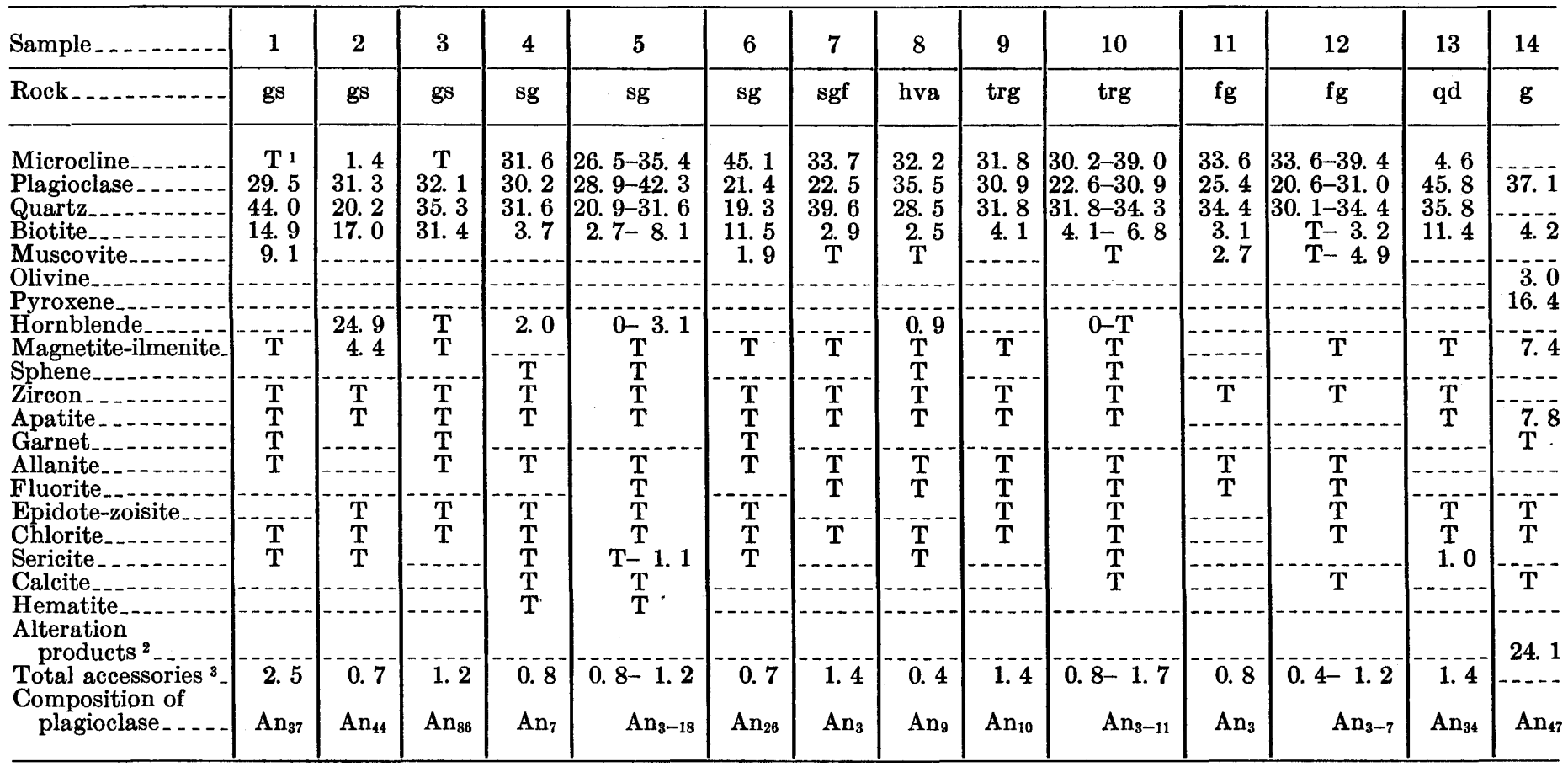

1 Trace.

2 Mostly amphibole, with some blotite, zoisite, chlorite, and clintonite (?).

Excluding those for which percentage is reported separately. 


\section{Source of samples :}

1. Precambrian (?) gneiss and schist; quartz-feldspar-biotite gneiss 0.96 mile $\$$. $42^{\circ} \mathrm{E}$. of northwest corner of quadrangle.

2. Precambrian (?) gneiss and schist : quartz-feldspar-hornblende-biotite gneiss; 0.27 mile $N$. $15^{\circ} \mathrm{E}$. of intersection of Moosup Valley and Bennett Hill Roads.

3. Precambrian (?) gneiss and schist ; feldspathic quartz-biotite schist 0.8 mile $\mathrm{S}$. $76^{\circ} \mathrm{E}$. of northwest corner of quadrangle.

4. Scituate granite gneiss; roadcut along Perry Hill Road 0.89 mile west of the Victory Highway.

5. Seituate granite gneiss; range in 4 thin sections of typical gneiss. 6. Scituate granite gneiss, sheared; along east edge of quadrangle $\mathbf{0 . 5 5}$ mile north of Harkney Hili Road.
7. Scituate granite gneiss, fine-grained facies; road cut 0.52 mile $\mathrm{N}$. $4^{\circ} \mathrm{E}$. of railroad crossing at Greene.

8. Hope Valley alaskite gneiss ; 1.48 miles $\mathrm{N}$. $35^{\circ} \mathrm{E}$. of the southwest

9. Ten Rod granite gneiss; quarry 0.16 mile northwest of church at Nooseneck.

10. Ten Rod granite gneiss; range in 4 thin sections.

11. Fine-grained granite; quarry 0.2 mile $S .15^{\circ} \mathrm{E}$. of top of Nipmuc Hill.

12. Fine-grained granite; range in 4 thin sections.

13. Quartz diorite gneiss; 0.71 mile $\mathrm{S}$. $74^{\circ} \mathrm{E}$. of the northwest corner

14. Gabbro quadrangle. quadrangle. 
3 inches thick, containing about 15 percent euhedral to subhedral metacrysts of white to flesh-colored microcline, commonly 1.5 inches across, crops out 0.41 mile S. $36^{\circ}$ E. of the intersection of Bennett Hill and Moosup Valley Roads.

The small body of gneiss and schist along Carpenter Road, southwest of Mount Misery, contains a few thin beds of fine-grained feldspathic quartzite.

\section{DEVONIAN(?) OR OLDER}

\section{SCITUATE GRANITE GNEISS}

The most widespread formation in the quadrangle is the Scituate granite gneiss. It is continuous northeastward with the Scituate granite gneiss of the type area (Quinn, 1951).

The Scituate granite gneiss is typically pinkish-gray or flesh-colored medium- to coarse-grained gneiss that contains about 3 to 8 percent biotite in flat, oval splotches commonly 20 by $50 \mathrm{~mm}$ but in places as much as 40 by $75 \mathrm{~mm}$. The splotches are concentrated in thin folia 2 to $10 \mathrm{~mm}$ apart and are generally so alined as to produce a strong lineation and moderate to weak foliation. The lineation is so characteristic that the rock has been called "lineated granite." Much of the gneiss is subporphyritic to porphyritic. Flesh-colored or greenish-gray ovoid to euhedral phenocrysts of microcline, 12 to $20 \mathrm{~mm}$ in cross section and as much as $40 \mathrm{~mm}$ long, locally constitute as much as 50 percent of the rock. In most places the long axis of each phenocryst is parallel to the lineation of the biotite splotches. The porphyritic fabric is seen best on surfaces perpendicular to the lineation; on other surfaces the rock appears almost even grained. Smoky quartz, pink potassium feldspar, white or gray-green plagioclase, biotite, magnetite, and locally garnet, hornblende, and sphene can be recognized megascopically. Typical Scituate granite gneiss is well exposed on the west slope of Mount Misery, along the Victory Highway just north of the Providence-Kent county line, and along the south shore of Quidnick Reservoir. Locally the gneiss is disintegrated to a depth as great as 10 feet.

Modes of typical Scituate granite gneiss are listed in table 1. In thin section the rock shows evidence of deformation after crystallization, for some biotite flakes and twin lamellae of plagioclase are bent, quartz shows strain shadows and some sutured borders, and microcline phenocrysts are granulated around the edges or are broken.

The origin of the phenocrysts is questionable. They are perthitic and some contain almost as much plagioclase (probable albite) as microcline, whereas the microcline of the groundmass is not perthitic. This suggests that the phenocrysts formed at a higher temperature, 
and are therefore probably older, than the microcline of the groundmass. Some phenocrysts enclose small grains of quartz, albite or oligoclase, biotite, and other groundmass minerals. These grains may be inclusions of early formed minerals in microcline crystallized during the magmatic stage, or they may be unreplaced remnants in late microcline formed from earlier plagioclase and groundmass minerals by metasomatism. Some of the granulated and broken phenocrysts are cut by veinlets of fine-grained albite or oligoclase, quartz, and microcline; along the edges of the veinlets, these minerals replace part of the phenocryst. Possibly the phenocrysts formed during the magmatic stage, included grains of earlier formed minerals, were subsequently granulated or broken, and were cut and partly replaced by the veinlets during the closing stages of crystallization of the magma.

Some of the plagioclase, especially that enclosed in the phenocrysts, has narrow rims of clear albite along the contacts of the grains of plagioclase and microcline. These albite rims may have been derived from the microcline by unmixing. Much of the quartz occurs as lenticular aggregates in the plane of foliation; the rest is in slightly flattened single grains or in tiny round to euhedral blebs in the microcline and the plagioclase. In some grains of feldspar, the numerous blebs of quartz are uniformly oriented, which they probably would not be if the quartz were originally in separate grains that were older than, and included in, the feldspar. If the blebs were remnants of a large grain of quartz replaced by feldspar, they probably would not show euhedral outlines. It appears that this quartz is in a graphic intergrowth with the feldspar and was formed at the same time as, or later than, the feldspar.

The Scituate granite gneiss around the Jackson quarry northwest of Stump Pond, and locally elsewhere, is finer and more nearly even grained than the typical Scituate, and has smaller splotches of biotite. At the quarry, the gneiss is medium grained, flesh colored, strongly lineated, and moderately foliated. The flat biotite splotches, about 5 by $15 \mathrm{~mm}$, are more evenly distributed than in most of the Scituate.

The Scituate is cut by numerous shear zones in outcrops along Harkney Hill Road at the east edge of the area 0.5 mile N. $37^{\circ} \mathrm{W}$. of the intersection of Harkney Hill and Phillips Hill Roads, along Plainfield Pike 0.8 mile southwest of Mount Vernon Church, and elsewhere.

The shear zones consist of irregularly spaced fairly straight single shears as much as several inches wide, or interweaving groups of shears as much as several tens of feet wide. The Scituate in the shear zones is fine-grained light- to medium-gray or pinkish-gray granulated gneiss, commonly having more biotite than is in the gneiss outside the shear zones, and locally having muscovite, chlorite, or aggregates 
of red-brown garnet as much as $15 \mathrm{~mm}$ across. The contact between granulated and ungranulated rock ranges from sharp to gradational. Some of the sheared rock, such as that 0.5 mile N. $37^{\circ} \mathrm{W}$. of the intersection of Harkney Hill and Phillips Hill Roads, is distinctly banded, having alternating dark, biotite-rich layers about $1 \mathrm{~mm}$ thick and flesh-colored, feldspar-rich layers commonly $5 \mathrm{~mm}$ thick. The shear zones and the cleavage in the shear zones in most places are not parallel with the foliation in the rock outside the shear zones. Likewise lineation, where present, is commonly not parallel to that in the unsheared rock.

Sheared Scituate along the east edge of the quadrangle 0.55 mile north of Harkney Hill Road has strong lineation, shown by thin splotches of biotite, and foliation of two ages. The older foliation is weakly developed and, like that in most of the Scituate, is present because the long and intermediate axes of the biotite splotches lie in the same plane. A thin section of the rock (table 1, column 6) shows that the younger foliation, which crosses the older at a high angle, is a result of the parallelism of the basal planes of both the biotite in the splotches and the much finer grained biotite scattered throughout the rock. The biotite is in subhedral flakes and none is bent or sheared; the quartz shows little granulation and only the largest grains show wavy extinction. Much recrystallization of minerals accompanied the formation of the shear cleavage. Sheared Scituate elsewhere contains fluorite, much anhedral garnet, as much as 2.5 percent calcite as interstitial grains or as a replacement of plagioclase, and albite rather than oligoclase.

A fine-grained facies of the Scituate granite gneiss, well exposed northwest of Potterville, north of Greene, and elsewhere, was mapped separately. This facies is fine grained, or locally medium grained, and has narrower, smaller, and fewer biotite splotches and better foliation than typical Scituate. The rock is flesh colored and has about 2 to 3 percent biotite in flat splotches commonly 5 by $25 \mathrm{~mm}$ scattered along thin folia about 3 to $6 \mathrm{~mm}$ apart. Like the rest of the Scituate, the fine-grained facies shows strong lineation and in places is porphyritic. The coarser parts are very similar to the finer grained parts of the normal Scituate. Some outcrops appear to be intermediate between the two facies; such rock was mapped as belonging to the facies most abundant in surrounding outcrops.

The relative age of the two facies of the Scituate is not known with certainty; it is believed that in part the two are equal in age and that in part the coarser Scituate is slightly older. Most of the rock in outcrops along the south-facing slope 0.8 mile north of the railroad crossing at Greene is the fine-grained facies of the Scituate, but some 
is like the coarser Scituate. In these outcrops, no sharp contact was observed and the two types appear to be gradational; this seems to be the relation, also, in outcrops about 0.35 mile east of bench mark 650 on the Victory Highway near the northern edge of the area. Along the west side of Cahoone Road, near the east end of the southfacing slope mentioned above, fairly typical Scituate contains several layers of what appears to be the fine-grained facies of the Scituate. These layers seem to be sills and therefore to be younger than the coarser Scituate.

\section{HOPE VALIEY ALASKITIE GNEISS}

The Hope Valley alaskite gneiss was named from exposures of pinkish-gray to flesh-colored gneiss in the southern part of the Hope Valley quadrangle (Moore, 1958) where it is characterized by a low content of dark minerals, by flattened rod-shaped aggregates of quartz producing a strong lineation, and in most places by conspicuous magnetite. It grades into the Scituate granite gneiss.

Several small concordant bodies of alaskite gneiss similar to that in the Hope Valley quadrangle are found in the southern half of the Coventry Center quadrangle. The gneiss is mostly medium grained and is flesh colored to pinkish gray. It contains 1 to 3 percent biotite, mostly in scattered splotches similar to those of the Scituate granite gneiss; flattened rod-shaped aggregates of quartz commonly 10 to 15 $\mathrm{mm}$ long; and, locally, anhedral to subhedral phenocrysts of pink potassium feldspar 15 to $20 \mathrm{~mm}$ long in amounts up to 15 percent of the rock. Texture and relations between minerals, as seen in thin sections, are like those of the Scituate granite gneiss. Much of the granite gneiss on Rock Hill, although mapped as Scituate, is difficult to distinguish from the alaskite gneiss.

\section{TRN ROD GRANITH GNEHSS}

The Ten Rod granite gneiss at the type locality in the Hope Valley quadrangle is pinkish gray to medium gray, fine to medium grained, and contains phenocrysts of salmon-colored microcline. It is intrusive into the Scituate granite gneiss (Moore, 1958). Similar gneiss in the Coventry Center quadrangle is correlated with the Ten Rod, although some of it is not porphyritic. Most of it occurs in the southern part of the area in relatively small, generally concordant bodies, some of which show local discordant contacts. This formation appears to be more resistant than the Scituate granite gneiss, for many outcrops consist of a sill or dike of Ten Rod a few feet thick, and a much thinner band of Scituate on one or both sides; numerous outcrops show only. a few feet of Ten Rod, possibly thin sills or dikes, but no wall rock. Some of the larger bodies of Ten Rod, such as the irreg- 
ularly shaped body west of Quidnick Reservoir, may consist in part of a swarm of sills and dikes, but the intervening Scituate is not exposed. The Ten Rod is well exposed around Weeks Hill, and in abandoned quarries at Nooseneck and at a point along the Victory Highway near the south edge of the quadrangle.

The Ten Rod granite gneiss of the Coventry Center quadrangle is fine to medium grained, gray or pinkish gray, and has moderate to strong foliation and lineation. Smoky quartz, flesh-colored potassium feldspar, white or gray plagioclase, biotite (2 to 5 percent), and scattered euhedral magnetite can be recognized megascopically. Most of the gneiss has a trace to about 5 percent phenocrysts of fleshcolored potassium feldspar, commonly 10 to $15 \mathrm{~mm}$ long; some contains as much as 20 percent phenocrysts, and some is even grained. The content of phenocrysts varies greatly even within a single body. Locally, phenocrysts of greenish-gray plagioclase are present in place of, or in addition to, those of potassium feldspar. Most of the phenocrysts are subhedral to euhedral; others appear to have been granulated and are now lens-shaped aggregates. Phenocrysts of quartz 3 to $5 \mathrm{~mm}$ in diameter occur locally in amounts as much as 5 percent. The lineation is expressed by streaks of biotite commonly 5 by $15 \mathrm{~mm}$ and in places by the feldspar phenocrysts.

Thin sections show that the average grain size of the groundmass is 0.2 to $0.4 \mathrm{~mm}$, though there are a few grains of all sizes up to that of the largest phenocrysts. Mineral relations are much like those observed in the Scituate granite gneiss. The larger grains of quartz have undulatory extinction and somewhat sutured borders; most smaller grains of quartz show neither. Perthitic texture is characteristic of the microcline phenocrysts but not of the microcline of the groundmass. Some grains of plagioclase have narrow rims of albite at the contacts of the grains of plagioclase and microcline. Modes are listed in table 1, columns 9 and 10.

The Ten Rod granite gneiss is intrusive into the Scituate granite gneiss in outcrops along the west side of the body of Ten Rod at Nooseneck, along the northeast side of the body near the south-central border of the area, and elsewhere. In an outcrop 0.41 mile N. $38^{\circ} \mathrm{W}$. of the railroad crossing at Summit, a dike of Ten Rod contains inclusions of the Scituate. The Ten Rod is thus younger than the Scituate. The Ten Rod is also younger than the Hope Valley alaskite gneiss, for the alaskite gneiss grades into the Scituate.

\section{FI NE-GRAINES GRANITE}

Numerous bodies of fine-grained granite, most of them apparently lens shaped, and sills, dikes, and irregular bodies of fine-grained 
granite too small to show at a scale of $1: 24,000$ are present in many places in the Scituate granite gneiss. The granite ranges from fine grained in larger bodies to very fine grained in smaller bodies, from light gray to flesh colored, and from strongly foliated and lineated to nearly massive. Minerals recognized megascopically are quartz, colorless to flesh-colored feldspar, generally 0.5 to 4 percent biotite, a trace to 2 percent muscovite, and scattered magnetite. The biotite is rather evenly distributed or is in streaks of slightly elongate flakes commonly 2 by $10 \mathrm{~mm}$, which produce the lineation. Most of the rock is even grained; the remainder contains as much as 20 percent pink potassium feldspar phenocrysts as much as $12 \mathrm{~mm}$ long.

The average grain size is 0.15 to $0.3 \mathrm{~mm}$; a few grains of quartz and feldspar are as much as $1.5 \mathrm{~mm}$ in diameter. Much of the quartz and feldspar is slightly flattened in the plane of the foliation, and the quartz commonly shows undulatory extinction and slight granulation. The plagioclase $\left(\mathrm{An}_{3}\right.$ to $\left.\mathrm{An}_{7}\right)$ is commonly polysynthetically twinned; the twin lamellae of a few grains are bent or broken. Some grains of plagioclase are bordered by narrow rims of clear albite along the contacts of the grains of plagioclase and microcline. The plagioclase, other than that in the narrow rims, is locally cloudy from alteration and inclusion. Most of the larger grains of microcline are perthitic whereas those of average grain size are not. Muscovite occurs as single flakes or is interleaved with biotite. Much of it is vermicular, ragged, contains streaks of hematite or magnetite, and appears to have replaced biotite. Modes are listed in table 1.

The fine-grained granite in the northern quarter of the quadrangle, particularly that on Nipmuc Hill, is much more slabby, has stronger foliation, contains more muscovite, and is grayer than that to the south. The granite in the quarries on Nipmuc Hill splits easily into slabs commonly 1 to 4 inches thick.

Dikes and sills of fine-grained granite, a few having inclusions of Scituate, intrude the Scituate in outcrops on Nipmuc Hill and elsewhere. The fine-grained granite likewise intrudes the fine-grained facies of the Scituate in outcrops 0.35 mile east of bench mark 650 on the Victory Highway near the north border of the area, 0.9 mile $\mathrm{N}$. $7^{\circ} \mathrm{W}$. of the railroad crossing at Greene, and along Cahoone Road 0.92 mile N. $22^{\circ} \mathrm{E}$. of this railroad crossing. In one place near Cahoone Road, however, eastward along the slope from the point 0.8 mile north of the railroad crossing, the fine-grained facies of the Scituate seems to grade into fine-grained granite like that on Nipmuc Hill. It appears then that most of the fine-grained granite is younger than the fine-grained facies of the Scituate but some of it is of the same age. 
The relative ages of the fine-grained granite and the Ten Rod granite gneiss are uncertain. Neither unit was observed to be intruded by the other, even in the several quarries where one or the other unit is excellently exposed. This suggests that the two might be equal in age.

\section{QUARTZ DIORITH GNHISS}

Quartz diorite gneiss is exposed near the northwest corner of the area in concordant bodies bordered by gneiss and schist; these are extensions of a large body of similar rock in the Clayville quadrangle.

The quartz diorite gneiss is light to medium gray, medium grained, and has lenticular structure. It is composed mainly of quartz, white feldspar, and rather evenly distributed clusters of biotite commonly 3 by 8 by $15 \mathrm{~mm}$. Most of the gneiss contains about 10 percent biotite; locally it contains as much as 20 percent. Subhedral phenocrysts, commonly $15 \mathrm{~mm}$ long, of white feldspar with Carlsbad twinning locally constitute 10 to 15 percent of the rock. The foliation is generally moderate to strong; lineation is generally weak or absent.

The gneiss as seen in thin section contains tabular plagioclase ${ } \mathbf{A n}_{34}$ to $\mathrm{An}_{37}$ ) commonly 3 to $4 \mathrm{~mm}$ long, quartz 1 to $2 \mathrm{~mm}$ long, accessory microcline, and clusters of biotite, all anhedral, in a matrix of feldspar and quartz commonly 0.2 to $0.5 \mathrm{~mm}$ in dimensions. This matrix makes up about 25 to 35 percent of the rock and occurs in borders, commonly 0.5 to $1.0 \mathrm{~mm}$ wide, along the larger grains and in irregular thin layers. The matrix appears to be a result of the crushing and granulation of larger grains. Bent biotite, bent twin lamellae of plagioclase, and wavy extinction and some sutured borders of quartz likewise indicate late stress. Most of the coarser plagioclase is riddled with tiny euhedral to anhedral grains of light green epidote and some is partly altered to sericite. Most of the plagioclase in the matrix is untwinned and unaltered. Sphene and allanite are prominent accessory minerals in much of the gneiss. A mode is listed in table 1. In a few places both the quartz diorite gneiss and the adjacent metasedimentary rock are intruded by sills and dikes of medium-grained to aplitic, massive to weakly foliated, very light gray rock composed of quartz, feldspar, and 1 to 2 percent biotite and muscovite. Most of these sills and dikes are less than 3 feet thick; a sill 0.49 mile $\mathrm{N}$. $15^{\circ} \mathrm{E}$. of the intersection of Bennett Hill and Moosup Valley Roads may be as much as 40 feet thick. Because their occurrence is local, these sills and dikes are assumed to be related to the quartz diorite.

The quartz diorite gneiss in outcrops at the north border of the area 0.4 mile west of Howard Hill Road appears to be intrusive into the metasedimentary rock. Just north of the border of the area, the quartz diorite contains diversely oriented inclusions of the meta- 
sedimentary rock. The quartz diorite is not in contact with other rock units in the Coventry Center quadrangle.

\section{DEVONIAN(?) OR OLDER TO PENNSYLVANIAN(?)}

\section{GABBRO}

The gabbro in the northwest corner of the area is a part of the elongate pluton that extends northwest into the three adjacent quadrangles. It is a uniformly coarse-grained grayish-black to grayishpurple rock in which tablets of grayish-purple plagioclase as much as $15 \mathrm{~mm}$ long and lesser amounts of pyroxene, biotite, ilmenite, and many euhedral prisms of yellowish apatite as much as $3 \mathrm{~mm}$ long can be identified megascopically. Moderate to strong foliation is characteristic of the gabbro; the foliation is expressed by the orientation of tablets of plagioclase and is believed to be primary.

The gabbro is exposed in low rounded knobs, a strikingly different topographic form from that shown by outcrops of adjacent rocks. Much of the exposed gabbro is disintegrated to a depth of as much as 10 feet, though some flow layers, commonly 1 to 2 feet thick, are not disintegrated and so project above adjacent layers. Such flow layers in places show pronounced spheroidal weathering with as many as six partly attached exfoliated shells around the central core.

A thin section of the gabbro exposed along Moosup Valley Road at the west border of the area (table 1, column 14) shows subdiabasic texture, and plagioclase $\left(\mathrm{An}_{47}\right)$, augite, olivine, ilmenite-magnetite, biotite, and apatite as the primary minerals. The olivine is partly replaced by augite and ilmenite-magnetite, probably in the magmatic stage. Alteration and replacement, probably deuteric, of the augite, biotite, and plagioclase by amphiboles and minor amounts of biotite, zoisite, chlorite, and clintonite (?) are widespread. Coronas of alteration minerals, mostly amphiboles, surround many of the grains of pyroxene, magnetite-ilmenite, and biotite, and extend outward into the plagioclase. The amphiboles present as alteration products, in order of decreasing age, are dark-green hornblende, felted masses of nearly colorless fibrous actinolitic hornblende, and green or greenishblue fibrous actinolitic hornblende arranged radially around the primary minerals. Zoisite occurs as scattered euhedral to subhedral grains, commonly $0.1 \mathrm{~mm}$ long, in blue, fibrous actinolitic hornblende between pyroxene and plagioclase, and it also occurs with calcite as dust-size particles in the plagioclase. The plagioclase, originally euhedral, is deeply embayed by amphibole coronas; as much as onethird of some grains has been replaced.

Gabbro exposed 0.69 mile N. $31^{\circ}$ W. of the intersection of Moosup Valley and Bennett Hill Roads has a color index similar to the gabbro 
described above but lacks olivine and pyroxene. It contains about 36 percent fine-grained blue-green actinolitic hornblende, partly in irregular to somewhat rectangular patches that suggest the former presence of pyroxene, but mostly in parallel veinlets 1 to $3 \mathrm{~mm}$ wide and 10 to $20 \mathrm{~mm}$ apart. The veinlets are nearly perpendicular to the foliation in the gabbro, have irregular borders, and are composed of acicular grains that lie across the veinlet and nearly in the plane of the foliation. The orientation of the hornblende in the veinlets, like that in the coronas described above, appears to be a result of differences in physico-chemical environment across a boundary and not a result of differential stress. Some of the plagioclase in this locality is zoned; the cores are cloudy from dust-size inclusions and have a composition of about $\mathrm{An}_{50}$, whereas the outer parts are clear and have a composition of about $\mathrm{An}_{37}$.

The gabbro is intrusive into the adjacent metasedimentary rocks. An inclusion or roof pendant of quartz-biotite schist in the gabbro is exposed 0.41 mile N. $23^{\circ}$ W. of the intersection of Bennett Hill and Moosup Valley Roads. The gabbro appears to be younger than the other units mapped, for it shows no effects of regional metamorphism whereas all other units have been so affected; it could be as young as Pennsylvanian or younger.

\section{Veins, PegMatTie, and APLITE}

Many outcrops of Scituate granite gneiss, Ten Rod granite gneiss, and fine-grained granite are cut by veins and pods of smoky quartz commonly a few inches to a foot wide; some are cut also by pegmatite and aplite. Many of these are parallel to strong joints or to the foliation in the country rock; others strike parallel to the trend of the lineation in the country rock. Most of the veins contain some microcline and a trace of plagioclase and biotite or magnetite, generally concentrated near the edges. Fluorite, hornblende, garnet, and sphene are present locally. Pods of quartz in an outcrop 400 feet southwest of the point where the road crosses McCuster Brook southeast of Scott Hollow contain crystals of hornblende as much as $40 \mathrm{~mm}$ long. A few quartz veins contain almost as much coarsegrained microcline as quartz; these appear to indicate transition from quartz veins into pegmatite.

Pegmatite and aplite in the formations mentioned above occur as sills, dikes, and irregular bodies, generally no more than a few inches wide. The pegmatite contains smoky quartz, pink microcline perthite, white plagioclase $\left(\mathrm{An}_{12}\right.$ in a pegmatite along the Victory Highway 0.32 mile north of the south edge of the area), biotite, and locally traces of muscovite, magnetite, garnet, or hormblende. Some of the 
pegmatite is zoned; small pods of pegmatite 0.44 mile west of the road corner at Summit have cores of quartz and outer layers, 0.5 to 1.0 inch wide, of pink microcline and a trace of magnetite. A narrow pegmatite in a roadcut 0.84 mile N. $6^{\circ} \mathrm{W}$. of the southeast corner of the area contains light-green amazonite, a trace of pyrite, and a few crystals of molybdenite in addition to the more common minerals listed above. Many of the grains of microcline in this pegmatite are in part green and in part flesh colored. In places, pegmatite grades laterally into aplite, which is flesh colored or light gray, and massive to weakly foliated and lineated. It commonly contains 1 to 2 percent biotite and muscovite, and locally traces of garnet. In sills it commonly has foliation parallel to the walls of the sills. Some aplite dikes have foliation parallel to the dike walls, whereas others, such as the one 0.53 mile S. $60^{\circ} \mathrm{E}$. of Mt. Vernon Church and some in road cuts along the Victory Highway 0.5 mile north of the south border of the area, have foliation and lineation parallel to that in the wallrock and discordant to the walls of the dikes. Aggregates, a few inches across, of coarse-grained hornblende or of hornblende, biotite, and sphene, some containing quartz and feldspar, occur locally in or along the margins of the quartz veins and pegmatite, and in the aplite.

Some pegmatites of southern Rhode Island are older than the Pennsylvanian or younger Westerly granite; others are younger than this granite (Dale, 1923, p. 405). The older ones contain anhedral microcline; most of the younger ones contain euhedral microcline. Most of the pegmatites in the granitic gneiss of the Coventry Center quadrangle contain anhedral microcline; these appear to be more like those older than the Westerly granite and appear to be genetically related to the granitic gneiss.

Pegmatite in the gabbro and in the adjacent quartz diorite and metasedimentary rock is unlike that described above. Pegmatite in the gabbro was observed only along the eastern margin of the pluton and is in irregular pods no more than 12 inches across. One of these is composed of white oligoclase $\left(\mathrm{An}_{22}\right)$ with lesser amounts of greenishblack actinolitic hornblende, small crystals of nearly colorless tremolitic amphibole, and ilmenite. The mineral composition of the pegmatites in the gabbro suggests that these pegmatites are genetically related to the gabbro.

Narrow dikes of quartz and white plagioclase in the quartz diorite and in the metasedimentary rock range from medium grained to pegmatitic; some of them have clusters of coarse-grained quartz along the center or coarse-grained hornblende along the edges. 


\section{SUMMARY OF AGE RELATIONS}

The Precambrian (?) gneiss and schist are the oldest rocks exposed, for inclusions of these occur in the Scituate granite gneiss, the quartz diorite gneiss, and the gabbro. The correlation of the gneiss and schist is somewhat uncertain; they probably belong to the Woonasquatucket formation or to the Blackstone series, both of Precambrian (?) age, and both older than the Scituate granite gneiss. The Scituate is older than the Pennsylvanian (Quinn, 1951) and younger than the gneiss and schist. The Scituate grades into the Hope Valley alaskite gneiss in a manner that indicates that the two are equal in age. The fine-grained facies of the Scituate grades into the coarser facies at most places where the relation can be determined. In a few places the fine-grained facies appears to be younger; the difference in age, at such places, is probably small. The Ten Rod granite gneiss intrudes the Scituate at several places in the area. The fine-grained granite is intrusive into the Scituate in most places where the relative ages can be determined, but in a few places the fine-grained granite appears to grade into the finegrained facies of the Scituate. The age of the Ten Rod relative to that of the fine-grained granite is uncertain, for neither was observed as intrusive into the other. The ages of the Ten Rod and the fine-grained granite relative to that of the Scituate suggest that the two may be approximately equivalent. The quartz diorite gneiss and the Scituate are not in contact in this quadrangle; their relative age is uncertain, though similarity in structure and in degree of metamorphism suggests that the ages of the two are not greatly different. The gabbro is younger than the gneiss and schist. Its lack of metamorphism indicates that it is the youngest unit mapped, and it may even be younger than the metamorphism that affected the Pennsylvanian rocks of the Narragansett basin.

\section{ORIGIN OF THE ROCKS}

The sedimentary origin of the gneiss and schist is indicated by bedding and by mineral composition. The few layers of hornblende schist in this unit may be volcanic.

The other units are believed to be igneous rocks intruded as liquid or partly liquid magma. Evidence of the origin of the Scituate granite gneiss and the Hope Valley alaskite gneiss was not observed in the Coventry Center quadrangle, but small dikes and sills of the Scituate intrude the Blackstone series in the North Scituate quadrangle (Quinn, 1951), and the Scituate cuts across the structure of the Woonasquatucket formation in the Georgiaville quadrangle (Richmond, 1952). Evidence of the igneous origin of the Hope Valley alaskite gneiss in the Hope Valley and Carolina quadrangles is given by Moore (1958, 
1959). Dikes of Ten Rod granite gneiss in the Scituate, some of which have flow structure parallel to the dike walls, are evidence of the igneous origin of the Ten Rod. Dikes of fine-grained granite, some having foliation parallel to the dike walls, can be seen in several places in the Scituate. The quartz diorite gneiss, in an outcrop 200 feet east of West Meadow Brook and 200 feet north of the Coventry Center quadrangle, contains some concordant and some diversely oriented discordant inclusions of metasedimentary gneiss; the quartz diorite must have been a liquid or mush in which the inclusions were suspended. R. J. Frost also described elongate discordant inclusions in the quartz diorite of the Clayville quadrangle. The gabbro contains inclusions of schist and is foliated but shows no indication of metamorphism. The foliation must be primary flow structure formed as the gabbro magma was intruded.

\section{STRUCTURAL GEOLOGY}

'The Coventry Center quadrangle lies in a crystalline complex that extends northward into Massachusetts and westward into Connecticut. About 12 miles east of the center of the quadrangle is the Narragansett basin, which trends northward across the eastern part of the State and is one of the major structural units of Rhode Island. The rocks in the basin are sedimentary rocks of Pennsylvanian age which, although complexly folded in places, have a general synclinal structure. Another north-trending basin of similar rocks, about 2 by 6 miles, has its center about 15 miles north-northeast of the center of the map area. The Pennsylvanian rocks of these basins overlie the older rocks with angular unconformity or nonconformity. Those along the west side of the Narragansett basin trend north and dip eastward, and overlie the west- to northwest-trending Precambrian(?) Blackstone series and bodies of plutonic rock. Most of Rhode Island west of the Narragansett basin is underlain by the Blackstone series or by plutonic rock of Devonian(?) or older age. The Devonian(?) or older igneous rock occurs as large concordant bodies or minor discordant bodies; the Blackstone occurs as inclusions or roof pendants in the plutonic rocks or as septa between them. Discordant intrusives of Mississippian(?) age, with associated volcanics, form the western margin of the basin near East Greenwich (Quinn, 1952) ; in the southern part of the State, Pennsylvanian or younger granite intruded both the Pennsylvanian rocks of the basin and the pre-Pennsylvanian rocks west of the basin.

In the Coventry Center quadrangle the structural pattern is shown by foliation in granitic gneiss, by lenticular intrusives, by bedding and foliation in metasedimentary rock, and by lineation. Over most of the area the foliation, lenticular intrusives, and bedding trend north or 
northeast and dip west or northwest at low to moderate angles; lineation plunges north-northwest at low to moderate angles. Locally the trend of the structure differs from that outlined above; near the northwest corner of the area the foliation in the gabbro appears to be parallel to the contacts of the body, and the varying strike of the bedding in the metasedimentary rock reflects folding.

\section{GNEISS AND SCHIST}

The gneiss and schist, in general, strike northward and dip westward at moderate angles but show evidence of considerable minor folding. In places the minor folds appear to be broad and open; in other places they are tight. The few minor folds whose attitudes could be measured plunge north or northwest at moderate or low angles; the axial planes dip steeply east. Bedding and foliation appear to be parallel in most places; locally they are not parallel.

\section{SCITUATE GRANITE GNEISS AND HOPE VALLEY}

\section{ALASKITE GNEISS}

The Scituate granite gneiss characteristically has strong lineation expressed by elongate splotches of biotite. Foliation in most of the rock is moderate to weak; the remainder lacks foliation. The lineation over most of the area plunges $15^{\circ}$ to $30^{\circ} \mathrm{N}$. or NNW.; that in the north and northwest part trends slightly more northward than that elsewhere. The foliation is more variable, though in most places it strikes north or northeast and dips $20^{\circ}$ to $40^{\circ} \mathrm{W}$. or NW. Shear zones and cleavage in the shear zones cross many outcrops of the Scituate. Although these zones, in general, strike northward and dip westward, the attitude varies from one locality to another. In most places, the shear zones and the cleavage cross the older foliation; locally they are parallel. The relative movement along most of the shear zones cannot be determined; in most places where it was determined, by drag of the older foliation or of lineation, the west side appears to have moved down and toward the north. The fine-grained facies of the Scituate has strong lineation and, in most places, distinct foliation. These are parallel to lineation and foliation in the adjacent coarser grained facies of the Scituate.

The Scituate grades locally into concordant lenticular bodies of the Hope Valley alaskite gneiss. The alaskite gneiss has strong lineation parallel with the lineation of the adjacent Scituate.

\section{TEN ROD GRANITE GNEISS}

The Ten Rod granite gneiss occurs as sills, dikes, and concordant lenticular bodies. The gneiss has moderate to strong foliation and 
lineation. In sills, the foliation and lineation are parallel to that in the surrounding rock. Some dikes of Ten Rod contain two foliations. A dike about 1 foot wide in the Scituate granite gneiss 800 feet $\mathrm{N}$. $70^{\circ} \mathrm{W}$. of the outlet of Carr Pond has a foliation parallel to the dike walls and a somewhat stronger foliation at a high angle to the dike walls and parallel to the foliation of the enclosing Scituate. The foliation parallel to the dike walls is shown by layers of biotite flakes; the basal cleavages of the flakes in these layers are mutually parallel but are inclined to the walls, resulting in the foliation that crosses the dike rock. The foliation parallel to the dike walls is believed to be primary flow structure. The foliation across the dike rock is believed to have formed later, at a time when deformation was guided by the foliation in the Scituate. A similar dike with two foliations is exposed 350 feet $\mathrm{N} .80^{\circ} \mathrm{W}$. of the sharp bend in the trail near the northeast end of Witford Pond.

Foliation in the Ten Rod parallel to that in the adjacent Scituate but across the contact between the two rocks can be observed in the exposure 0.47 miles S. $73^{\circ}$ E. of the road intersection on Weeks Hill, in Scott Hollow 0.56 mile N. $32^{\circ}$ E. of bench mark 521 on the Victory Highway, 0.2 mile N. $65^{\circ} \mathrm{W}$. of the 478 road intersection north of Quidnick Reservoir, and elsewhere. Because several dikes of the Ten Rod show primary foliation, the foliation in sills of this rock is assumed to be primary also; the primary foliation in these sills is parallel to that in the enclosing Scituate. The later deformation that produced foliation across the dikes of the Ten Rod was guided by the primary foliation in the Scituate.

\section{FINE-GRAINED GRANITE}

Most of the fine-grained granite has strong foliation and moderate lineation; some in smaller bodies is nearly massive. The foliation in sills and lenticular bodies of this granite is parallel to the contacts of these bodies, and both foliation and lineation are parallel to the foliation and lineation in the wallrock. A few small dikes have weak foliation parallel to the dike walls; along other dikes and along locally discordant contacts, the foliation in the granite cuts across the contact. In the outcrop along the north side of Turkey Meadow Brook 125 feet east of the Plainfield Pike, in some of those along the trail south from the road intersection near the top of Nipmuc Hill, and elsewhere, cross-cutting contacts between the granite and the country rock are exposed for at least a few feet. At these places, the foliation in the granite is parallel to that in the country rock and across the contact, and lineation in the granite is parallel to the lineation in the country rock. Such relations are like some described for the Ten Rod 
granite gneiss and are believed to have the same origin as those in the Ten Rod.

\section{QUARTZ DIORITE GNEISS}

The quartz diorite gneiss occurs as concordant sheets in the enclosing metasedimentary rocks. Foliation in the quartz diorite is somewhat irregular, but in most of the rock it strikes northward and dips steeply westward. Most of the quartz diorite does not show lineation. Where present, lineation is expressed by streaks of biotite flakes and plunges north-northwest at a low angle.

\section{GABBRO}

The gabbro has strong to moderate foliation expressed by tabletshaped grains of plagioclase. Because the mineral grains show no granulation or bending and because the strikes of the foliation in the gabbro, the contact, and the foliation in the country rock appear to be parallel in those places where the contact of the gabbro can be located most accurately, the foliation is considered to be primary flow structure. The foliation can best be explained as resulting from the flow of magma parallel to the walls of the body.

\section{METAMORPHISM}

The rocks of Rhode Island show evidence of two, and perhaps three, periods of metamorphism. The oldest, if there were three, was Precambrian. Woodworth (Shaler and others, 1899, p. 105) pointed out the evidence for metamorphism of this age: the Blackstone series in the Blackstone Valley of northeastern Rhode Island is much more metamorphosed than is the red fossiliferous Cambrian shale and slate in North Attleboro, Mass., 4 miles to the east. 'This difference in metamorphism between the two areas suggests that the metamorphism of the Blackstone series is Precambrian, but the difference might be a result of rapid lateral change in the intensity of a later metamorphism. The second period of metamorphism, if there were three, was one of repeated or continuing metamorphism related to the emplacement of the Devonian (?) or older plutons. If the Blackstone series was not metamorphosed during the Precambrian, then it and older rocks were metamorphosed during the early part of the igneous activity and before the emplacement of the Hope Valley alaskite gneiss, because the alaskite gneiss in the Carolina quadrangle contains inclusions of metasedimentary rocks that have foliation inclined at a high angle to that in the surrounding alaskite gneiss (Moore, 1958). Metamorphism apparently belonging to this period but younger than the alaskite gneiss is shown by mineral granulation and alteration, shear zones, and recrystallization of minerals along the shear zones in several 
related plutonic formations of Devonian(?) or older age. A distinctly younger period of metamorphism occurred after the deposition of the Pennsylvanian sedimentary rocks of the Narragansett basin but before the intrusion of the Pennsylvanian or younger granites of southern Rhode Island. This metamorphism produced distinct schistosity, and mineral changes indicative of middle-grade metamorphism, in some of the Pennsylvanian sedimentary rocks.

The oldest metamorphism of the rocks in the Coventry Center quadrangle is represented by the foliation and the mineral composition of the Precambrian(?) gneiss and schist. These rocks were subjected to regional metamorphism before the intrusion of the Hope Valley alaskite gneiss and the quartz diorite gneiss because both contain diversely oriented inclusions of the gneiss and schist. Most of these metasedimentary rocks were originally shale, which was changed to quartz-feldspar-biotite gneiss and schist, some of which contains traces of garnet. The few thin beds of quartzite were originally impure sandstone, and the hornblende schist was either impure carbonate rock or mafic volcanic rocks. Coarse biotite and hornblende, and traces of garnet indicate middle-grade metamorphism. The metamorphism may have taken place without the addition of much material. Schistosity in these rocks is parallel to the bedding in most places; locally it is at a high angle to the bedding. The age of this metamorphism could range from Precambrian to Devonian(?).

A subsequent period of metamorphism was initiated by the emplacement of the Devonian (?) or older intrusives and resulted in much feldspar in gneiss and schist adjacent to the intrusives. The feldspar may have formed by recrystallization of the material already present or from material added by the invading solutions. In the mapped area much feldspar occurs in the metasedimentary rocks adjacent to the quartz diorite gneiss; in nearby areas the amount of feldspar increases with proximity to the Scituate granite gneiss, the Hope Valley alaskite gneiss, or other Devonian (?) or older intrusives (Richmond, 1952; Moore, 1958). High shearing stress must have existed at different times during the emplacement of these intrusives, for a foliation across many of the discordant bodies of Ten Rod granite gneiss and fine-grained granite is parallel to the primary flow structure in the enclosing rock. Muscovite, present in some of the fine-grained granite in appreciable amounts, may have formed at this time. The effectiveness of shearing stresses must have declined before the last intrusion, for some dikes do not show the foliation across the dikes. Mineral granulation, shown most distinctly by the Scituate and Ten Rod granite gneisses, may be of about the same age as the foliation across the discordant bodies. 
A younger time of high shearing stress is indicated by shear zones and cleavage in the shear zones, present locally in the Scituate and Ten Rod granite gneisses. The shear zones and cleavage, in general, strike northward and dip westward, and in most places are not parallel to the primary flow structure of the rocks involved. The rock in the shear zones has been granulated, as indicated by its fine texture. Cleavage is expressed by oriented flakes of biotite and muscovite and by ellipsoidal aggregates of quartz and feldspar. The shear zones locally contain much muscovite, and clusters of garnet as much as 0.25 inch in diameter. The shear zones, cleavage, and new minerals are believed to have formed near the end of the Devonian(?) or older orogeny, but they could have formed in the Pennsylvanian. Sedimentary rocks of Pennsylvanian age 6 miles northeast of the northeast corner of the quadrangle have been complexly folded and metamorphosed, and contain muscovite, garnet, biotite, and feldspar as metamorphic minerals (Quinn, 1951); the age of this metamorphism has been dated elsewhere as Pennsylvanian. If the shear zones and the associated cleavage described above are Devonian(?) or older in age, the effects of the Pennsylvanian metamorphism are not apparent in the mapped area.

\section{ECONOMIC AND ENGINEERING GEOLOGY}

Ten Rod granite gneiss has been removed from a quarry between Nooseneck and Yard Pond, from one along the Victory Highway near the south edge of the area, and from smaller quarries elsewhere. These quarries appear to have been abandoned many years ago. Scituate granite gneiss has been removed from several openings, one of them about 425 feet long, at the Jackson quarry, northwest of Stump Pond. The quarry was worked until 1926 for paving block and curbstone, most of which was used in Rhode Island and Connecticut. Some building block is reported to have been shipped to New York City about 1922. In recent years a little veneer stone for houses has been quarried. Fine-grained granite has been quarried from openings on both sides of the county line south and southeast of Nipmuc Hill; there are small quarries elsewhere. The rock from Nipmuc Hill, known locally as the Nipmuc granite, is strongly foliated very light gray fine-grained granite containing as much as 2 percent muscovite and 2 percent biotite. The rock splits readily into thin slabs and in places is closely jointed. These quarries were extensive as early as 1840 ; the stone was used as platforms, ashlar stones, and building stone (Jackson, 1840, p. 76). The condition of the roads into the quarry indicates that some stone has been removed in recent years. 
Most of the unweathered bedrock of the area is suitable for use as construction material and foundations. It is generally strong, hard, and resistant to weathering. Most of it will stand in vertical walls; where it is closely jointed or strongly foliated the rock tends to slip along these planes of weakness. The gabbro in the northwestern part of the area is probably the strongest rock; the metasedimentary rock is the weakest.

In places, the Scituate granite gneiss and the gabbro have disintegrated into rottenstone to a depth as great as 10 feet. The most extensive areas of exposed rottenstone are shown on the map. This material, so friable that it can be dug with a shovel, has been used locally as road metal.

There are no known metallic mineral deposits of economic importance in the area. A long-abandoned shaft 0.27 mile S. $70^{\circ} \mathrm{E}$. of bench mark 643 at the intersection of the Victory Highway and the Plainfield Pike is reported by local residents to have been opened in search of gold. The walls of the now partly filled shaft, about 12 feet across and 10 feet deep, show strongly jointed quartz stained with much limonite along the joints. The quartz appears to be in veins and pods sheeted parallel to the foliation in the enclosing rock.

Glacial deposits of sand and gravel are the most valuable mineral resources of the quadrangle. These are most extensive and thickest beneath terraces along major streams. Most of the sand and gravel is hard and sound, but in and to the south of the areas of rottenstone the deposits include some of this rottenstone. Glacial till constitutes most of the surface material in the upland. The till is generally very sandy and has been used for fill and road bases.

Wells drilled into sand and gravel provide the largest supply of water; those drilled into glacial till or into bedrock provide a domestic water supply in many places. Because the unweathered and unbroken bedrock of the area is highly impermeable, the most productive wells in bedrock are those in rottenstone or those that intersect fissures. Rottenstone is present only locally and it generally extends no more than about 10 feet below the bedrock surface. The distribution of fissures is such that it is generally not possible to predict where, or at what depth, these could be penetrated by a well. 


\section{LITERATURE CITED}

Dale, T. N., 1923, The commercial granites of New England : U.S. Geol. Survey Bull. 738. 488 p.

Jackson, C. T., 1840, Report on the geological and agricultural survey of the State of Rhode Island : Providence, R.I., $312 \mathrm{p}$.

Moore, G. E., Jr., 1958, Bedrock geology of the Hope Valley quadrangle, Rhode Island : U.S. Geol. Survey Geol. Quad. Map GQ-105.

1959 , Bedrock geology of the Carolina and Quonochontaug quadrangles, Rhode Island : U.S. Geol. Survey Geol. Quad. Map GQ-117.

Quinn, A. W., 1951, Bedrock geology of the North Scituate quadrangle, Rhode Island : U.S. Geol. Survey Geol. Quad. Map GQ-13.

1952, Bedrock geology of the East Greenwich quadrangle, Rhode Island : U.S. Geol. Survey Geol. Quad. Map GQ-17.

Quinn, A. W., Jaffe, H. W., Smith, W. L., and Waring, C. L., 1957, Lead-alpha ages of Rhode Island granitic rocks compared to their geologic ages: Am. Jour. Sci., v. 255, p. 547-560.

Richmond, G. M., 1952, Bedrock geology of the Georgiaville quadrangle, Rhode Island : U.S. Geol. Survey Geol. Quad. Map GQ-16.

Shaler, N. S., Woodworth, J. B., and Foerste, A. F., 1899, Geology of Narragansett Basin : U.S. Geol. Survey Mon. 33, 402 p. 